BADAN PENDIDIKAN DAN PELATIHAN KEUANGAN KEMENTERIAN KEUANGAN REPUBLIK INDONESIA

\section{JURNAL BPPK}

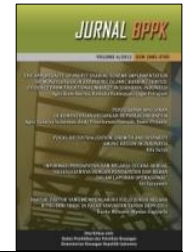

\title{
IMPLEMENTASI PEMBERIAN HIBAH PEMERINTAH INDONESIA KEPADA PEMERINTAH/LEMBAGA ASING SEBAGAI STIMULUS SOFT DIPLOMACY
}

\author{
Taraf Kurniadi \\ Direktorat Evaluasi, Akuntansi dan Setelmen, DJPPR, Kementerian Keuangan \\ Email: taraf.kurniadi@kemenkeu.go.id, alltaraf@gmail.com
}

\section{INFO ARTIKEL}

SEJARAH ARTIKEL

Diterima Pertama

09 Juli 2019

Dinyatakan Dapat Dimuat 30 Juni 2020

\section{KATA KUNCI:}

Hibah,

Pemerintah/Lembaga Asing, Soft Diplomacy,

Direktorat Evaluasi,

Akuntansi,

Setelmen,

KPA Belanja Hibah.

\begin{abstract}
ABSTRAK
Providing grants which are intended for the foreign governments/institutions is Indonesia's soft diplomacy stimulus either for humanitarian or non-humanitarian such as conducted in 2014-2018. The purpose of this article is to describe how the business process of providing grants carried out by KPA Belanja Hibah c.q. Directorate of Evaluation, Accounting and Settlement by identifying a number of gaps in the factors that influence providing grants to foreign governments /institutions as an Indonesian soft diplomacy stimulus. Based on the previous literature and regulations, this study found that providing grants carried out by KPA Belanja Hibah had not yet been optimal because there were dynamics in budget allocation and disbursement. Eventhough it have been governed by regulations such as PP 45 Tahun 2013 and PMK No.92/MK.08/2014, there are some issues such as the new proposal budget if the grant expenditure passes one fiscal year and the grant flexibility which is only limited to cash. For these reasons, it is necessary to simplify the business process of providing grants to foreign governments /institutions so that the implementation becomes faster, more efficient, and accountable.
\end{abstract}

\begin{abstract}
Pemberian hibah kepada pemerintah/lembaga asing merupakan salah satu stimulus soft diplomacy di dunia internasional baik untuk tujuan kemanusiaan maupun non kemanusiaan kepada pemerintah/lembaga asing seperti yang dilakukan Pemerintah Indonesia pada tahun 2014-2018. Tujuan artikel ini adalah mendeskripsikan bagaimana proses bisnis pemberian hibah ini dilaksanakan KPA Belanja Hibah c.q. Direktorat Evaluasi, Akuntansi dan Setelmen dengan mengidentifikasikan sejumlah gap pada faktor-faktor yang mempengaruhi pemberian hibah kepada pemerintah/lembaga asing sebagai stimulus soft diplomacy Indonesia. Berdasarkan analisis literatur dan kebijakan/regulasi, kajian ini menemukan bahwa pemberian hibah yang dilaksanakan KPA Belanja Hibah belum optimal karena terdapat sejumlah dinamika dalam pengalokasian anggaran dan pencairannya. Meskipun telah dipayungi regulasi seperti PP 45 Tahun 2013 dan PMK Nomor 92/MK.08/2014, masih terdapat kendala seperti dalam usulan baru lagi jika belanja hibah melewati tahun anggaran berjalan dan fleksibilitas hibah yang hanya terbatas diberikan secara tunai (cash). Untuk itu, diperlukan simplifikasi proses bisnis pemberian hibah kepada pemerintah/lembaga asing agar pelaksanaannya menjadi lebih cepat, efisien, dan akuntabel.
\end{abstract}

\section{PENDAHULUAN}

\subsection{Latar Belakang}

Pemerintah Indonesia menjalankan politik luar negeri bebas aktif di dunia internasional dan merupakan interaksi dan hubungan kerjasama dan persahabatan dengan pemerintah negara lain, organisasi internasional, dan juga masyarakat internasional.

Dewasa ini, interdependensi antarnegara menjadi semakin intens sehingga menjadikan tidak ada satu negara pun di dunia ini yang dapat memenuhi kebutuhan dalam negerinya sendiri. Hubungan Kerjasama baik bilateral maupun multilateral menjadi hal yang jamak dilakukan sebagai salah satu instrumen untuk memanfaatkan peluang dan kesempatan dalam mencapai kepentingan nasionalnya.

Diplomasi merupakan elemen penting untuk menunjukkan eksistensi suatu negara dalam kancah dunia internasional untuk memelihara kebijakan luar negeri suatu pemerintahan negara dalam mempengaruhi kebijakan dan sikap pemerintah 
negara lain. Saat ini, diplomasi bukan hanya aktivitas politik saja, tetapi diplomasi juga menyangkut aspek multi-dimensional seperti aspek isu ekonomi, sosialbudaya, hak asasi manusia dan lingkungan hidup untuk menciptakan perdamaian dalam percaturan politik global serta mencapai kepentingan nasional suatu negara.

Dalam hubungan internasional, munculnya soft power sebagai alternatif hard power dan membawa implikasi pada pelaksanaan diplomasi suatu negara. Soft power lebih menunjukan daya tarik (attractiveness) suatu negara dibandingkan dengan hard power yang menunjukkan kekuatan dan kekerasan.

Soft diplomacy adalah suatu cara pendekatan diplomasi suatu negara melalui aspek ekonomi, sosial maupun budaya dalam upaya pencapaian tujuan nasionalnya. Sedangkan hard diplomacy adalah pendekatan diplomasi suatu negara dengan hard power, seperti kekuatan militer.

Dengan soft power, suatu negara memperoleh sasaran kepentingannya di percaturan politik dunia internasional terhadap negara lain karena samasama menemukan titik persamaan kepentingannya tanpa adanya unsur paksaan. Yang ada hanya unsur ketertarikan atau keterpikatan.

Beberapa penelitian telah dilakukan untuk mengungkapkan peran soft diplomacy dalam perkembangan hubungan internasional. Menurut Sumaryo Suryokusumo (2004), diplomasi merupakan proses politik untuk memelihara kebijakan luar negeri suatu Pemerintah dalam mempengaruhi kebijakan dan sikap Pemerintah negara lain. Yanyan Mochamad Yani dan Eluovani Lusiana (2018) mengungkapkan batas dan definisi praktik konsep soft diplomacy sebagai bagian dari perkembangan konsep diplomasi publik kontemporer. Menurut Andri Hadi (2008), soft diplomacy lebih menekankan pada pembentukan dan pemeliharaan citra positif suatu negara. György Szondi (2009) mengungkapkan sasaran soft diplomacy adalah berkaitan dengan reputasi, tidak hanya perubahan perilaku (behavior) -membuat seseorang melakukan sesuatu, namun juga mencakup perubahan sikap (attitude), seperti mendukung atau setidaknya tidak menentang - politik luar negeri suatu negara.

Srivastava (2013) membedakan konsep soft diplomacy dengan konsep soft power. Soft diplomacy sebagai practice of the foreign policy by any nation state or any regional organization not exclusively focused to serve its national interests but to help any other country in distress due to economic or political problem in its domestic or external domain. Soft diplomacy merupakan kebijakan luar negeri suatu negara atau organisasi regional untuk membantu negara lain yang dalam kesulitan karena masalah ekonomi atau politik dalam negeri maupun global karenanya ditawarkan bantuan ekonomi meskipun bukan satu-satunya dan penyelesaian konflik yang mencakup arbitrasi, atau bantuan dalam negosiasi damai. Pendekatan semacam itu dapat dipertimbangkan sebagai urusan amal (charitable affair).

Kelaziman yang dilakukan pemerintah suatu negara dalam konteks soft diplomacy hubungan internasional adalah salah satu di antaranya memberikan bantuan yang bersifat tidak mengikat atau hibah (grant) kepada berbagai negara yang membutuhkan dan mempunyai hubungan diplomatic dengan Indonesia. Tujuan pemerintah dalam memberikan hibah diantaranya adalah untuk kemanusiaan pascabencana, peningkatan kesejahteraan, ekonomi, sosial dan budaya sebagai upaya peningkatan hubungan kerjasama dengan negara dan menciptakan kawasan yang kondusif bagi kepentingan nasional.

Status Indonesia yang menjadi negara berpendapatan menengah (lower middle-income country) membawa perubahan di mana Pemerintah Indonesia mereposisi perannya dalam hubungan internasional. Pemerintah yang dulunya lebih banyak bertindak sebagai beneficiary country sedikit bergeser ke arah contributor country. Pada titik inilah, Indonesia dalam percaturan lingkungan internasional memberikan hibah ke pemerintah/ lembaga asing dan dipahami bahwa hakikat pemberian hibah merupakan salah satu stimulus soft diplomacy di dunia hubungan internasional yang bertujuan untuk mendukung pencapaian kepentingan nasionalnya.

Menteri Keuangan selaku pengelola fiskal berwenang mengelola anggaran belanja hibah di mana kewenangan tersebut termasuk memberikan hibah kepada pemerintah/lembaga asing yang secara teknis dilaksanakan oleh KPA Belanja Hibah yang dalam hal ini Direktur Evaluasi, Akuntansi dan Setelmen.

\subsection{Identifikasi Permasalahan}

Kajian ini akan berusaha menjawab beberapa permasalahan sebagai berikut:

a. Bagaimana mekanisme pemberian hibah kepada pemerintah/lembaga asing yang dilaksanakan DJPPR c.q. Direktorat Evaluasi, Akuntansi dan Setelmen periode 2014-2018?

b. Faktor-faktor yang mempengaruhi pelaksanaan pemberian hibah pemerintah Indonesia ke pemerintah/lembaga asing.

\subsection{Tujuan Penelitian}

a. Mendeskripsikan mekanisme dan proses bisnis pemberian hibah kepada pemerintah/lembaga asing dilaksanakan DJPPR c.q. Direktorat Evaluasi, Akuntansi dan Setelmen periode 20142018.

b. Mengidentifikasi faktor-faktor dan permasalahan yang mempengaruhi pelaksanaan pemberian hibah pemerintah Indonesia ke pemerintah/lembaga asing sebagai stimulus soft diplomacy Indonesia. 


\section{KERANGKA BERPIKIR}

\subsection{Definisi Belanja Hibah}

Berdasarkan Buletin Teknis Standar Akuntansi Pemerintah Nomor 13 tentang Akuntansi Hibah, pengertian Belanja Hibah adalah belanja pemerintah dalam bentuk uang/barang/jasa yang dapat diberikan kepada pemerintah negara lain, organisasi internasional, pemerintah pusat/daerah, perusahaan negara/ daerah, kelompok masyarakat, atau organisasi kemasyarakatan yang secara spesifik telah ditetapkan peruntukannya, bersifat tidak wajib dan tidak mengikat, serta tidak secara terus menerus kecuali ditentukan lain dalam peraturan perundangundangan.

PMK No. 271/PMK.05/ 2014 tentang Sistem Akuntansi dan Pelaporan Hibah dan PMK No. 92/PMK.08/2014 tentang Pelaksanaan Belanja Hibah ke Pemerintah Asing/ Lembaga Asing mendefinisikan belanja hibah adalah setiap pengeluaran pemerintah pusat berupa pemberian yang tidak diterima kembali, dalam bentuk uang, barang, jasa, dan/atau surat berharga yang secara spesifik telah ditetapkan peruntukannya. Beban hibah adalah setiap kewajiban pemerintah pusat dalam bentuk uang/barang atau jasa kepada penerima hibah bersifat tidak wajib dan tidak mengikat.

Sedangkan dalam PMK No. 92/PMK.08/2014 tentang siapa yang berhak menerima hibah menyebutkan bahwa pemerintah asing/lembaga asing merupakan pemerintah/lembaga yang berasal dari luar negeri yang menerima hibah dari Pemerintah Indonesia.

\subsection{Arsitektur Pelaksanaan Belanja Hibah Pemerintah Indonesia kepada Pemerintah/Lembaga Asing}

Arsitektur pelaksanaan belanja hibah ke pemerintah/lembaga asing merupakan suatu kerangka dasar yang menyeluruh dan memberikan arah, bentuk, serta tatanan pelaksanaan hibah ke pemerintah/lembaga asing. Arsitektur ini lahir dari dinamika kebutuhan dan cara pelaksanaan hibah dari alokasi anggaran hibah, KPA dan mekanisme pencairan sampai dengan tanggung jawab pelaksanaan belanja hibahnya.

Peraturan yang terkait dengan hibah adalah sebagai berikut:

1. Undang-Undang Nomor 17 Tahun 2003 tentang Keuangan Negara pasal 23 ayat (1) dan UndangUndang Nomor 1 Tahun 2004 tentang Perbendaharaan Negara pasal 33 ayat (2) menyebutkan bahwa Pemerintah Pusat dapat memberikan hibah/pinjaman kepada atau menerima hibah/pinjaman dari pemerintah/ lembaga asing dengan persetujuan DPR sesuai dengan yang ditetapkan dalam Undang-Undang tentang APBN.

2. Peraturan Pemerintah Nomor 45 Tahun 2013 tentang Pelaksanaan APBN pasal 103 ayat (5), (6), (7) dan (8) mengatur bahwa Menteri Keuangan selaku pengelola fiskal berwenang mengelola anggaran belanja hibah, Menteri Keuangan bertindak selaku PA atas anggaran belanja hibah, Menteri Keuangan menunjuk pejabat setingkat eselon I di lingkungan Kementerian Keuangan untuk menjalankan fungsi PA dan menetapkan pejabat pada Kementerian Keuangan selaku KPA

3. Peraturan Menteri Keuangan Nomor 92/MK.08/2014 tentang Pelaksanaan Belanja Hibah ke Pemerintah Asing/Lembaga Asing Pasal 2 ayat (1) mengatur tentang pelaksanaan Belanja Hibah ke Pemerintah Asing/Lembaga Asing pada tahun anggaran berjalan. Selanjutnya dalam Pasal 4 ayat (4) menyebutkan bahwa Menteri Keuangan selaku Pengguna Anggaran (PA) atas anggaran Belanja Hibah menetapkan pejabat di lingkungan Direktorat Jenderal Pengelolaan Utang (c.q. DJPPR) sebagai Kuasa Pengguna Anggaran (KPA) Belanja Hibah. Dalam Pasal 8 disebutkan bahwa Kuasa Pengguna Anggaran (KPA) Belanja Hibah bertanggung jawab atas transfer Belanja Hibah dari rekening kas negara ke rekening Pemerintah Asing/Lembaga Asing penerima hibah. Hal lainnya yang diatur dalam Pasal 2 adalah bahwa hibah kepada pemerintah/lembaga asing diberikan dalam tahun anggaran berjalan dan dalam bentuk uang.

4. Dalam Pasal 4 ayat (3) Peraturan Menteri Keuangan Nomor 204/MK.02/2014 jo Nomor 100/MK.02/2015 tentang Tata cara Pergeseran Anggaran Belanja Antar Subbagian Anggaran dalam Bagian Anggaran 999 (BA BUN) disebutkan bahwa pergeseran anggaran belanja dari BA BUN pengelolaan Belanja Lainnya (BA 999.08) ke BA BUN Pengelolaan Hibah (BA 999.02) dilakukan untuk pemberian hibah ke pemerintah/lembaga asing untuk tujuan kemanusiaan dan selain kemanusiaan yang telah mendapat persetujuan DPR.

Menurut PMK No. 92/PMK.08/2014, ada tiga hal pokok yang dapat dideskripsikan dalam arsitektur pelaksanaan hibah kepada pemerintah/lembaga asing, yaitu:

a. Komitmen politik.

Hibah ke pemerintah/lembaga asing timbul dengan adanya pledge presiden/direktif presiden. Komitmen Kepala Negara ditetapkan dalam keputusan Presiden/arahan Presiden lainnya dalam bentuk risalah sidang kabinet yang diterbitkan Sekretariat Kabinet.

Usulan keputusan Presiden/direktifnya dipersiapkan kementerian/lembaga selaku inisiator/pemrakarsa kegiatan yang sekaligus bertanggung jawab atas anggaran dan keluaran (output) hibah.

UU APBN tahun anggaran berjalan memberikan wewenang kepada pemerintah untuk memberikan hibah kepada pemerintah/ lembaga asing dan menetapkan penerimanya baik untuk tujuan kemanusiaan maupun tujuan 
lainnya.

b. Penganggaran

Ketentuan PMK Nomor 92/MK.08/2014 tentang Pelaksanaan Belanja Hibah ke Pemerintah Asing/Lembaga Asing mengatur mekanisme penganggaran hibah ke pemerintah/lembaga asing dilakukan pada tahun anggaran berjalan. Mekanisme penganggarannya dilakukan dengan pergeseran anggaran belanja antar subbagian anggaran dalam BA BUN dari BA BUN 999.08 Pengelolaan Belanja Lainnya ke BA BUN 999.02 Pengelolaan Hibah sesuai ketentuan PMK Nomor 93/MK.02/2013 jo 87/MK.02/2015 jo 208/PMK.02/2017 tentang Tata Cara Penggunaan dan Pergeseran Anggaran Pada BA BUN Pengelolaan Belanja Lainnya (BA 999.08).

Selanjutnya pergeseran anggaran belanja tersebut ditetapkan dengan Surat Penetapan Pergeseran Anggaran Belanja Antar Subbagian Anggaran dalam Bagian Anggaran Bendahara Umum Negara (SPP-BA BUN) yang menjadi dasar penetapan DIPA BA 999.02 Pengelolaan Hibah dan sekaligus menjadi dasar pelaksanaan transfer belanja hibah kepada pemerintah/lembaga asing oleh KPA.

c. PA dan KPA belanja hibah

PP 45/2013 tentang Pelaksanaan APBN menjelaskan bahwa Menteri Keuangan selain Pengguna Anggaran (PA) bagian anggaran kementerian yang dipimpinnya, juga selaku PA atas bagian anggaran yang tidak dikelompokkan dalam bagian anggaran Kementerian Negara/Lembaga (BUN).

Selaku pengelola fiskal yang berwenang mengelola anggaran belanja hibah, Menteri Keuangan yang merupakan PA menunjuk pejabat setingkat eselon I untuk menjalankan fungsi PA dan menetapkan pejabat pada Kementerian Keuangan selaku KPA.

KPA Belanja Hibah bertanggung jawab secara formal atas transfer Belanja Hibah dari rekening kas negara ke rekening pemerintah/ lembaga asing penerima hibah karena kegiatan yang dibiayai bukan merupakan tugas dan fungsi Kementerian Keuangan.

Kementerian/Lembaga bertanggung jawab atas realisasi anggaran dan pencapaian keluaran (output) kegiatan karena Kementerian/ Lembaga merupakan inisiator atau pemrakarsa kegiatan teknis pelaksanaan pemberian hibah kepada pemerintah/lembaga asing sesuai dengan tugas dan fungsi pokoknya.

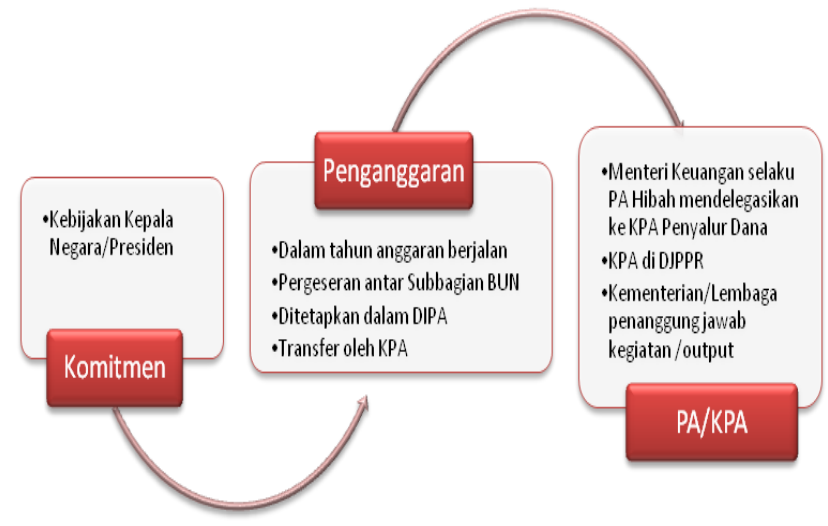

Gambar 1.

Arsitektur Pelaksanaan Hibah Kepada Pemerintah/Lembaga Asing Mengacu PMK No. 92/PMK.08/2014

\subsection{Soft Diplomacy}

Politik luar negeri RI yang bebas aktif pada hakikatnya berlandaskan pada tujuan nasional bangsa Indonesia di alinea keempat Pembukaan UUD 1945 yaitu ikut melaksanakan ketertiban dunia yang berdasarkan kemerdekaan, perdamaian abadi dan keadilan sosial. Langkah konkritnya adalah dengan ikut memberikan bantuan/ sumbangan baik dalam bentuk pemikiran maupun keikutsertaan kita secara aktif dalam hubungan internasional.

Mochtar Kusumaatmadja (dalam Arista, 2016) mengemukakan pendapatnya mengenai konsep politik bebas aktif. Arti kata "Bebas" sebagai sikap Indonesia yang tidak memihak pada kekuatankekuatan negara lain yang tidak sesuai dengan nilainilai luhur Pancasila. Sedangkan "Aktif" adalah bahwa Indonesia dalam kebijakan politik luar negerinya tidak bersikap pasif-reaktif atas kejadian yang terjadi di dunia internasional, melainkan bersifat aktif dalam hubungan antar negara dan tidak sebagai objek, sehingga Indonesia tidak dapat dikendalikan oleh haluan politik negara lain yang berdasarkan pada kepentingan-kepentingan nasional negara lain itu sendiri.

Menurut Enggartias Wahana Putera (2018), ada tiga elemen penting untuk berinteraksi dengan dunia internasional yaitu actors, interest dan power. Actors adalah para pelaku yang bisa sebagai pemerintahan suatu negara yang berperan penting atau actors lain yang disebut sebagai nonstate actors, misalnya: nongovernmental organization (NGO) dan multinational corporations (MNCs). Elemen berikutnya dalam interaksi dengan dunia internasional adalahinterest. Interest atau kepentingan merupakan langkah awal yang harus dilakukan pelaku untuk memulai melakukan interaksi. Power atau kekuasaan merupakan elemen ketiga dalam interaksi dengan dunia internasional.

Diplomasi adalah bagian integral negara dalam melaksanakan hubungan internasionalnya. Diplomasi sebagai upaya suatu bangsa untuk 
mencapai kepentingan nasional dan instrumen dalam pelaksanaan kebijakan politik luar negeri, tentunya ditunjang oleh power yang dimiliki suatu negara. Timbulnya soft power sebagai alternatif hard power berimplikasi pada langkah-langkah diplomasi suatu negara. Soft diplomacy yang merupakan pendekatan diplomasi suatu negara untuk mencapai tujuan nasionalnya melalui aspek ekonomi, sosial maupun budaya mengalami perkembangan dari bentuk yang tradisional menjadi diplomasi yang lebih modern dengan pendekatan yang lebih lembut dan bersifat persuasif yakni dengan menggunakan soft power.

Soft power yang dipopulerkan Joseph Nye (2004) bersumber pada "cultural attraction, ideology, and international institutions" dan diasumsikan sebagai

"the ability of a state to get other countries to want what it wants" dan "ability to get what you want through attraction rather than coercion or payments."

Cara soft power ini berlawanan dengan hard power yang mengimplikasikan inducements (carrots/ imbalan) or threats (sticks/ancaman)".

Soft diplomacy adalah bentuk diplomasi kultural seiring dengan tidak populernya penggunaan hard power suatu negara untuk mencapai kepentingannya sejak berakhirnya era perang dingin.

Soft diplomacy dilakukan dengan memikat (attraction) yang membuat orang lain membenarkan pandangan dan akhirnya setuju dengan pendapat kita. Jika pihak lain setuju, maka kita mendapatkan apa yang diinginkan tanpa harus memerintah ataupun memaksanya.

Srivastava (2013) membedakan konsep soft diplomacy dengan konsep soft power. Soft diplomacy tergantung pada bantuan dan mediasi dan pada dasarnya bersifat normatif, di sisi lain soft power bergantung pada penerapan budaya dan hubungan terkait lainnya dalam memperoleh tujuan. Srivastava mendefinisikan soft diplomacy sebagai practice of the foreign policy by any nation state or any regional organization not exclusively focused to serve its national interests but to help any other country in distress due to economic or political problem in its domestic or external domain. Soft diplomacy mencakup bantuan ekonomi yang ditawarkan tetapi bukan satu-satunya mekanisme operasional dan penyelesaian konflik yang kompleks yang mencakup arbitrasi, atau bantuan dalam negosiasi damai juga dimediasi dengan mekanisme soft diplomacy. Pendekatan semacam itu dapat dipertimbangkan sebagai urusan amal (charitable affair).

Modalitas pemerintah Indonesia untuk menjalankan soft diplomacy adalah karakter (character), kapabilitas (capability), dan akseptabilitas (acceptability) Indonesia di kancah dunia internasional yang bercirikan sebagai negara demokrasi yang besar, penduduknya yang mayoritas Islam moderat, negara berhaluan politik bebas aktif, culture yang khas seperti norma, value, cara pandang dan negara dengan sejarah panjang dalam berbagai organisasi internasional baik sebagai deklarator ataupun inisiator yang diterima dengan baik oleh negara-negara lain di dunia .

\section{METODOLOGI PENELITIAN}

Menurut Sudarwan Danim (2002), penelitian kualitatif deskriptif yaitu data yang dikumpulkan berbentuk kata-kata, gambar, bukan angka-angka.

Menurut Bogdan dan Taylor, sebagaimana dikutip oleh Lexy J. Moleong, penelitian kualitatif adalah prosedur penelitian yang menghasilkan data deskriptif berupa kata-kata tertulis atau lisan dari orang-orang dan perilaku yang diamati. Sementara itu, penelitian deskriptif adalah suatu bentuk penelitian yang ditujukan untuk mendeskripsikan atau menggambarkan fenomena-fenomena yang ada, baik fenomena alamiah maupun rekayasa manusia.

Metode penelitian yang digunakan dalam kajian ini termasuk dalam metode penelitian deskriptif kualitatif dengan menggunakan metode studi literatur dan kebijakan/regulasi yang terkait dengan permasalahan penelitian.

Pertama, penulis mempelajari data dan informasi relevan yang terkait dengan pelaksanaan pemberian hibah ke pemerintah asing/lembaga asing yang ada pada Direktorat Evaluasi, Akuntansi dan Setelmen, DJPPR. Selanjutnya dengan berdasarkan informasi ini, penulis mengidentifikasi dan memetakan bagaimana pelaksanaan skema pemberian hibah ke pemerintah/lembaga asing dilakukan.

Kedua, berdasarkan studi regulasi terkait, penulis mengobservasi pelaksanaan pemberian hibah kepada pemerintah/lembaga asing dalam rangka mendukung diplomasi luar negeri Indonesia di kancah dunia internasional.

\section{HASIL PENELITIAN}

Secara keseluruhan, hasil analisis dan pembahasan kajian akan dibagi dalam bisnis proses pelaksanaan belanja hibah kepada pemerintah/lembaga asing, implementasi pemberian hibah kepada pemerintah/lembaga asing tahun 2014-2018, faktor-faktor yang mempengaruhi pemberian hibah sebagai stimulus soft diplomacy, fakta dan permasalahan dalam pelaksanaan pemberian hibah kepada pemerintah/lembaga asing tahun 2014-2018. Penjelasan lebih lanjut dapat diuraikan sebagai berikut:

\subsection{Bisnis Proses Pelaksanaan Belanja Hibah Kepada Pemerintah/Lembaga Asing}

Pelaksanaan pemberian hibah ke pemerintah/lembaga asing merujuk kepada ketentuan PMK 92/MK.08/2014 tentang Pelaksanaan Belanja Hibah ke Pemerintah Asing/Lembaga Asing. Di samping itu juga mengacu 
kepada SOP (Standar Operasional Prosedur) yang ada pada Direktorat EAS. Menurut PMK No.131/PMK.01/2015 tentang Pedoman Penyusunan Proses Bisnis, Kerangka Pengambilan Keputusan, dan Standar Operasional Prosedur di Lingkungan Keuangan, SOP merupakan serangkaian instruksi tertulis yang dibakukan mengenai berbagai proses penyelenggaraan administrasi pemerintahan, bagaimana dan kapan harus dilakukan serta di mana dan oleh siapa dilakukan.

Adapun tahapan pelaksanaannya adalah sebagai berikut :

\subsubsection{Penetapan KPA Belanja Hibah oleh Menteri Keuangan selaku PA BUN}

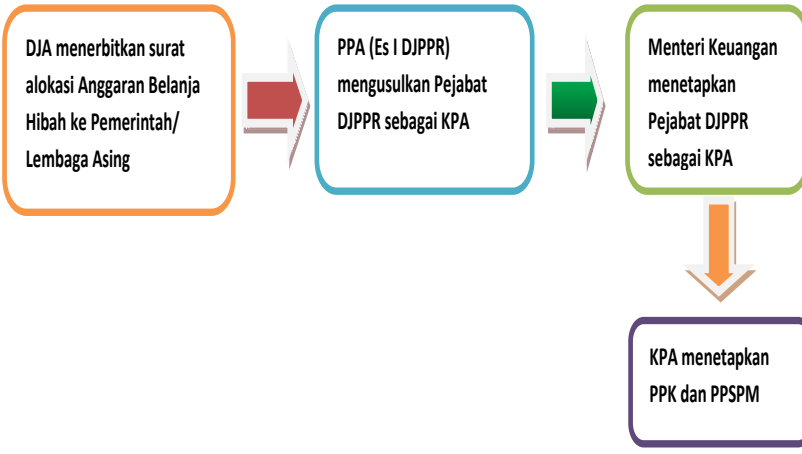

Gambar 2.

Penetapan KPA Belanja Hibah oleh Menteri Keuangan Mengacu pada PMK No. 92/PMK.08/2014

Penyusunan usulan penetapan KPA Belanja Hibah oleh Menteri Keuangan selaku PA BUN dalam rangka pelaksanaan belanja hibah kepada pemerintah/lembaga asing mengacu pada PMK 92/MK.08/2014 dan SOP-PR.8.EU-15 tentang Penyusunan Usulan KMK Penunjukkan KPA dalam Rangka Pelaksanaan Belanja Hibah kepada Pemerintah/Lembaga Asing pada Direktorat EAS Secara ringkas prosedur yang berlaku adalah sebagai berikut:

1 Dirjen Anggaran atas nama Menteri Keuangan menerbitkan surat alokasi belanja hibah ke pemerintah/lembaga asing.

2 Berdasarkan surat alokasi belanja hibah, Dirjen Pengelolaan Pembiayaan dan Risiko selaku PPA BUN mengusulkan pejabat di lingkungan DJPPR sebagai KPA Belanja Hibah kepada Menteri Keuangan.

3 Berdasarkan usulan tersebut, Menteri Keuangan menetapkan pejabat yang diusulkan sebagai KPA Belanja Hibah. KPA Belanja Hibah berperan menyalurkan dana ke pemerintah/lembaga asing sesuai peraturan perundang-undangan

$4 \quad$ KPA menetapkan pejabat perbendaharaan yakni penandatangan SPM dan Pejabat Pembuat Komitmen (PPK) untuk menyelesaikan transaksi transfer belanja hibah ke pemerintah/lembaga asing.

\subsubsection{Penetapan DIPA/Revisi DIPA BA 999.02 Pengelolaan Hibah Kegiatan Belanja Hibah Kepada Pemerintah/Lembaga Asing}

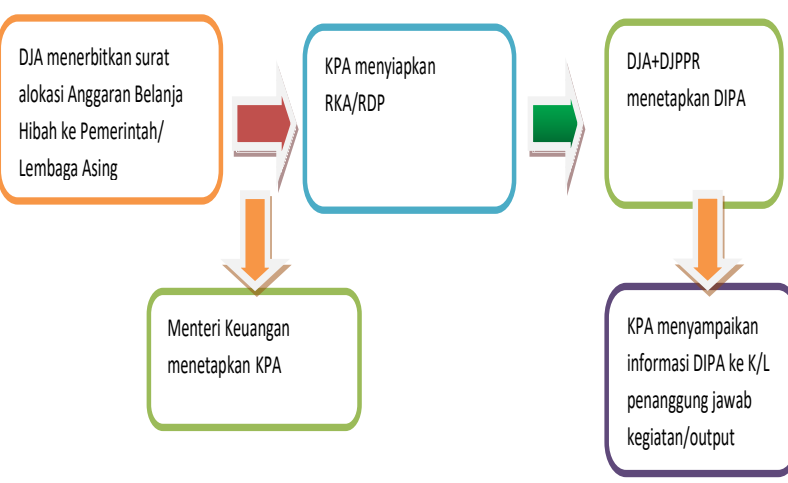

Gambar 3

Penetapan DIPA/Revisi BA 999.02 Kegiatan Belanja Hibah Kepada Pemerintah/Lembaga Asing Mengacu pada PMK No. 92/PMK.08/2014

Secara ringkas prosedur yang berlaku adalah sebagai berikut:

1. Dirjen Anggaran atas nama Menteri Keuangan menerbitkan surat alokasi belanja hibah ke pemerintah/lembaga asing

2. Berdasarkan surat alokasi anggaran belanja hibah/ Surat Penetapan Pergeseran Anggaran Belanja Antar Subbagian Anggaran dalam Bagian Anggaran Bendahara Umum Negara (SPP-BA BUN), KPA menyusun Rencana Kerja Anggaran (RKA) sebagai bahan Rencana Dana Pengeluaran (RDP) PPA

3. DJA menelaah usulan RKA/RDP DJPPR dan dituangkan dalam Daftar Hasil Penelaahan (DHP) yang menjadi dasar penetapan DIPA/Revisi BA BUN 999.02 Pengelolaan Hibah. DIPA/Revisi BA BUN 999.02 tersebut menjadi dasar pelaksanaan transfer belanja hibah ke pemerintah/lembaga asing oleh KPA

4. KPA selanjutnya menginformasikan kepada Eselon I Kementerian/ Lembaga penanggung jawab kegiatan/pencapaian output atas penyelesaian DIPA dan sekaligus meminta dokumen dukung pencairan yaitu:

a. Salinan Rekening Koran Pemerintah/ Lembaga Asing Penerima Hibah

b. SPTJM atas pelaksanaan kegiatan yang ditandatangani Eselon I

c. Surat Keterangan Rekening Pemerintah/ Lembaga Asing Penerima Hibah

SOP-PR.8.ET-15 tentang Penganggaran BA BUN 999.02 Pengelolaan Hibah Kegiatan Pelaksanaan Belanja Hibah kepada Pemerintah Asing/Lembaga menjadi rujukan dalam usulan penetapan DIPA/Revisi DIPA BA 999.02 Pengelolaan Hibah Kegiatan Belanja Hibah Kepada Pemerintah/Lembaga Asing. Kegiatan yang 
dilaksanakan meliputi kegiatan pemberitahuan adanya alokasi belanja hibah kepada pemerintah/lembaga asing, penyusunan RKA/RDP BUN, penyampaian RDP BUN, penerbitan DIPA/revisinya dan penyampaian DIPA/Petunjuk Operasional Kegiatan (POK) kepada pihak terkait. SOP yang tersebut menggambarkan mekanisme penyediaan dana belanja hibah kepada pemerintah/lembaga asing pada tahun berjalan dalam lingkup pengelolaan Direktorat EAS.

\subsubsection{Pengujian Dokumen Pencairan Belanja Hibah}

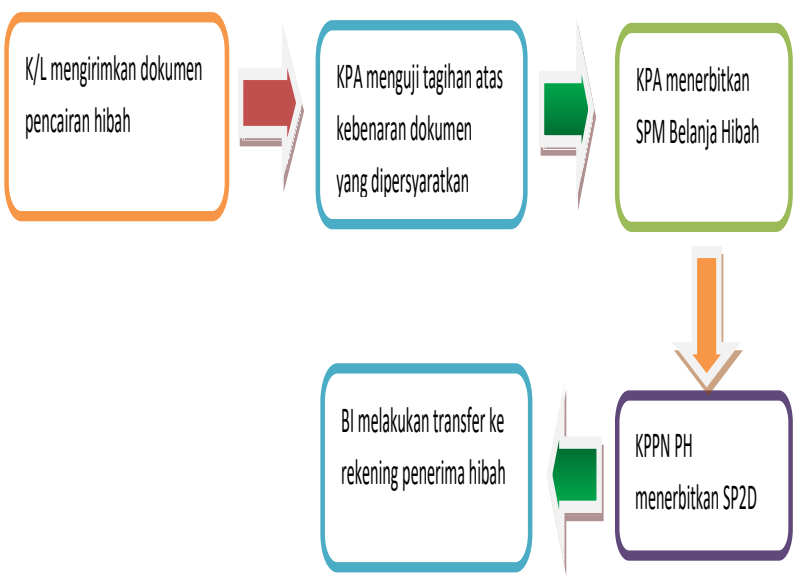

Gambar 4

Pengujian Dokumen Pencairan Belanja Hibah Mengacu pada PMK No. 92/PMK.08/2014

1. KPA menerima dokumen Permintaan Pencairan Belanja Hibah dari Kementerian/Lembaga selaku penanggung jawab belanja hibah

2. KPA meneliti dan melakukan pengujian dokumen permintaan pencairan sesuai dengan kriteria pada Peraturan Menteri Keuangan 92/PMK.08/2014

3. KPA melakukan proses pencairan dengan menerbitkan Surat Perintah Membayar (SPM) setelah pengujian dokumen permintaan pencairan sesuai dengan kriteria peraturan yang berlaku.

4. KPPN Pinjaman dan Hibah menerbitkan Surat Perintah Pencairan Dana (SP2D) sebagai dokumen yang digunakan sebagai dasar pencairan dana yang diterbitkan Bendahara Umum Negara.

5. Bank Indonesia selanjutnya melakukan transfer ke rekening penerima hibah.

Di samping PMK No. 92/MK.08/2014, SOP-PR.8EV-15 tentang Pengujian Dokumen Pencairan Belanja Hibah ke Pemerintah/Lembaga Asing, dan SOP-PR.8EW-15 tentang Pelaksanaan Pencairan Belanja Hibah ke Pemerintah/Lembaga Asing menjadi pedoman operasional Direktorat EAS pelaksanaan pengujian dan pencairan belanja hibah ke Pemerintah/Lembaga Asing beserta SOP-PR.8-FG-16 tentang Penyampaian Informasi Pencairan Belanja Hibah kepada Kementerian/Lembaga selaku penanggung jawab kegiatan dan output.

\subsubsection{Penyusunan Laporan Keuangan Hibah}

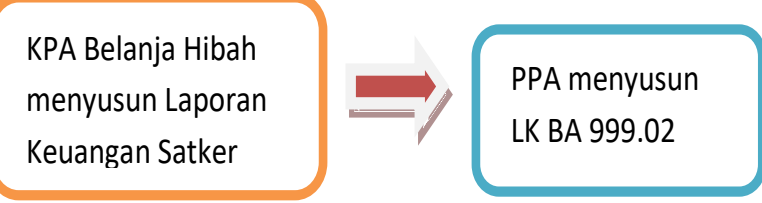

Gambar 5

Penyusunan Laporan Keuangan Hibah Mengacu pada PMK No. 92/PMK.08/2014

1. KPA Belanja Hibah menyusun LRA, Neraca, Laporan Operasional, Laporan Perubahan Ekuitas, dan Catatan Atas Laporan Keuangan Satker DJPPR. LRA dan Neraca disusun bulanan dan semesteran. Sementara lainnya semesteran.

2. KPA Belanja Hibah menyampaikan ke PPA laporan keuangan dimaksud dan dikonsolidasikan dengan laporan belanja hibah dalam kelolaan PPA BUN 999.02 Pengelolaan Hibah

Sebagaimana ketentuan Pasal 9 PMK No. 92/MK.08/2014, tata cara pelaporan dan pelaksanaan belanja hibah ke pemerintah/lembaga asing mengacu pada PMK tentang sistem akuntansi hibah yakni PMK 271/PMK.05/2014.

\subsection{Implementasi Pemberian Hibah Kepada Pemerintah/Lembaga Asing 2014-2018}

Sebelum berlakunya PP 45 Tahun 2013, pemberian hibah dilakukan kementerian/lembaga negara secara langsung karena pengaturan tentang belanja hibah ke luar negeri belum dituangkan dalam suatu regulasi tertentu. Salah satu contoh pemberian hibah ke luar negeri sebelum adanya PP 45 Tahun 2013 diantaranya adalah: hibah pembangunan rumah sakit Indonesia di Palestina sebesar Rp.20 miliar di tahun 2011, hibah kemanusiaan ke pemerintah Myanmar dan Suriah masing-masing sebesar Rp.9,71 miliar dan Rp.4,84 miliar pada awal 2013. Namun alokasi untuk Suriah tidak bisa direalisasikan karena terdapat masalah dalam selisih kurs. Kendala tersebut menjadi salah satu pemikiran untuk memperbaiki mekanisme pemberian hibah kepada pemerintah/lembaga asing.

PP 45 Tahun 2013 merupakan salah satu titik balik pelaksanaan pemberian hibah ke pemerintah/lembaga asing dimana Menteri Keuangan selaku pengelola fiskal berwenang mengelola anggaran belanja hibah dan menetapkan pejabat di Kementerian Keuangan selaku KPA Belanja Hibah. Jadi secara policy, lead pemberian hibah tetap 
pada kementerian/lembaga selaku inisiator/ pemrakarsa kegiatan dan sekaligus penanggung jawab atas pelaksanaan kegiatan dan pencapaian outputnya. Sedangkan, Kementerian Keuangan yang mengelola fiskal memberikan kepastian berapa alokasi hibah yang bisa diberikan sesuai dengan kapasitas fiskal pemerintah.

Langkah konkrit atas pelaksanaan PP 45 Tahun 2013 terkait dengan hibah ke pemerintah/lembaga asing lebih lanjut dirumuskan dalam PMK Nomor 92/MK.08/2014 tentang Pelaksanaan Belanja Hibah Ke Pemerintah Asing/Lembaga Asing. Dengan dasar PMK inilah, Direktorat Evaluasi, Akuntansi dan Setelmen melaksanakan tugas dan fungsinya dalam menyalurkan belanja hibah ke pemerintah asing/lembaga asing.

Dalam pelaksanaannya PMK tersebut memerlukan penyempurnaan lebih lanjut dengan dilakukannya revisi PMK Nomor 92/MK.08/2014 dengan PMK Nomor 3/PMK.08/2016 antara lain tentang ketentuan pelaksanaan reviu APIP Kementerian Keuangan dalam hal usulan belanja hibah ke pemerintah/lembaga asing dialokasikan pada BA 999.02 Pengelolaan Hibah tidak melalui pergeseran anggaran BA BUN. Disamping itu, pencairan belanja hibah bisa dilakukan dengan menggunakan valuta asing/rupiah.

Pemerintah Indonesia telah mengalokasikan hibah untuk 16 penerima (beneficiaries) dan direalisasikan untuk 14 penerima baik pemerintah/lembaga asing dalam periode 20142018. Dua penerima sisanya tidak dapat merealisasikannya pada tahun anggaran berjalan atau direalisasikan pada tahun anggaran berikutnya. Total realisasi belanja hibahnya adalah Rp.205,5 miliar. Semua hibah kepada pemerintah/lembaga asing tersebut diberikan dalam tahun anggaran berjalan dan dalam bentuk uang.

Hibah pembangunan asrama mahasiswa Indonesia di Al Azhar Cairo, Mesir tahun 2014 merupakan realiasasi pertama kali sejak PP 45 Tahun 2013 dan PMK Nomor 92/MK.08/2014 ditetapkan. Hibah pembangunan asrama ini dilatarbelakangi oleh kekurangan dana pembangunan asrama mahasiswa Indonesia di Al Azhar Cairo dengan sumber dana awalnya berasal dari DIPA Kementerian Agama, donasi masyarakat Indonesia dan sumbangan beberapa provinsi yang digalang oleh Kementerian Agama. Hibah yang diberikan merupakan upaya menutup kekurangan biaya dalam pembangunan asrama mahasiswa tersebut dan sebagai upaya mengurangi risiko additional cost akibat terjadinya fluktuasi perubahan harga dan denda keterlambatan pembayaran.

Pada tahun 2014, hibah kepada IMAAM (Indonesian Muslim Association in America) Center, Maryland, USA direalisasikan atas permintaan masyarakat Indonesia di Maryland kepada Presiden untuk pembelian dan renovasi tempat ibadah berupa masjid. IMAAM Inc. sendiri merupakan organisasi non profit yang bergerak di bidang pendidikan, amal, keagamaan, dan kegiatan sosial dan kebudayaan yang mensponsori kegiatan masyarakat muslim Indonesia di Washington DC, Maryland dan Virginia.

PEMBERIAN HIBAH KEPADA PEMERINTAH ASING/LEMBAGA ASING 2014-2018

\begin{tabular}{|c|c|c|c|c|}
\hline No & KEGIATAN & PENGUSUL KEGIATAN & KPA & REALISASI \\
\hline \multicolumn{5}{|c|}{ TAHUN 2014} \\
\hline 1 & $\begin{array}{l}\text { Hibah untuk Pembangunan Asrama Mahasiswa } \\
\text { Indonesia, Al Azhar, Cairo, Mesir }\end{array}$ & $\begin{array}{l}\text { Kementerian Pendidikan } \\
\text { Nasional }\end{array}$ & \begin{tabular}{|l|} 
Direktur Evaluasi, \\
Akuntansi dan Setelmen \\
\end{tabular} & 33,41 \\
\hline 2 & Hibah kepada IMAAM Center di, Maryland, USA & Kementerian Agama & $\begin{array}{l}\text { Direktur Evaluasi, } \\
\text { Akuntansi dan Setelmen }\end{array}$ & 34,54 \\
\hline \multirow[t]{4}{*}{3} & Hibah Kemanusian kepada Pemerintah: & \multirow[t]{4}{*}{ Kementerian Luar Negeri } & \multirow{4}{*}{$\begin{array}{l}\text { Direktur Evaluasi, } \\
\text { Akuntansi dan Setelmen }\end{array}$} & \\
\hline & a. Suriah & & & \\
\hline & b. Serbia, Bosnia Herzegovina (BIH) & & & 3,73 \\
\hline & c. Palestina & & & \\
\hline \multicolumn{5}{|c|}{ TAHUN 2015} \\
\hline 1 & \begin{tabular}{|l|} 
Hibah Pembangunan Masjid di IIC Kabul, \\
Afghanistan
\end{tabular} & Kementerian Agama & \begin{tabular}{|l} 
Direktur Evaluasi, \\
Akuntansi dan Setelmen \\
\end{tabular} & 5,00 \\
\hline 2 & $\begin{array}{l}\text { Hibah Pembangunan Masjid di Queensland, } \\
\text { Australia } \\
\end{array}$ & Kementerian Luar Negeri & \begin{tabular}{|l|} 
Direktur Evaluasi, \\
Akuntansi dan Setelmen \\
\end{tabular} & 5,00 \\
\hline 3 & Pemerintah Palau untuk Pasific Island Forum II & Kementerian Luar Negeri & $\begin{array}{l}\text { Direktur Evaluasi, } \\
\text { Akuntansi dan Setelmen }\end{array}$ & 12,50 \\
\hline 4 & Hibah Kemanusiaan kepada Palestina & \multirow[t]{2}{*}{ Kementerian Luar Negeri } & \multirow{2}{*}{\begin{tabular}{|l|} 
Direktur Evaluasi, \\
Akuntansi dan Setelmen
\end{tabular}} & 14,06 \\
\hline 5 & Hibah Kemanusiaan kepada Suriah (UNOCHA) & & & 7,03 \\
\hline \multicolumn{5}{|c|}{ TAHUN 2016} \\
\hline 1 & Pemerintah Laos untuk Keketuaan ASEAN 2016 & Kementerian Luar Negeri & \begin{tabular}{|l} 
Direktur Evaluasi, \\
Akuntansi dan Setelmen \\
\end{tabular} & 13,11 \\
\hline \multicolumn{5}{|c|}{ TAHUN 2017} \\
\hline 1 & $\begin{array}{l}\text { Hibah untuk Sekretariat Melanesian Spearhead } \\
\text { Group (MSG) }\end{array}$ & Kementerian Luar Negeri & \begin{tabular}{|l} 
Direktur Evaluasi, \\
Akuntansi dan Setelmen
\end{tabular} & 22,65 \\
\hline \multicolumn{5}{|c|}{ TAHUN 2018} \\
\hline 1 & Pemerintah Guinea Bissau untuk kemanusiaan & Kementerian Luar Negeri & \begin{tabular}{|l} 
Direktur Evaluasi, \\
Akuntansi dan Setelmen \\
\end{tabular} & 25,34 \\
\hline 2 & Pemerintah Papua Nugini untuk kemanusiaan & Kementerian Luar Negeri & \begin{tabular}{|l|} 
Direktur Evaluasi, \\
Akuntansi dan Setelmen \\
\end{tabular} & 7,16 \\
\hline 3 & $\begin{array}{l}\text { Pemerintah Fiji untuk kemanusiaan pasca } \\
\text { bencana }\end{array}$ & Kementerian Pertanian & \begin{tabular}{|l|} 
Direktur Evaluasi, \\
Akuntansi dan Setelmen \\
\end{tabular} & 5,80 \\
\hline 4 & $\begin{array}{l}\text { Pemerintah Afghanistan untuk pembangunan } \\
\text { klinik kesehatan di IIC Kabul }\end{array}$ & Kementerian Kesehatan & $\begin{array}{l}\text { Direktur Evaluasi, } \\
\text { Akuntansi dan Setelmen }\end{array}$ & 16,17 \\
\hline
\end{tabular}

Sumber: Direktorat Evaluasi Akuntansi dan Setelmen DJPPR

Di samping itu, terdapat alokasi hibah kemanusiaan untuk Suriah dalam rangka membantu pengungsi Suriah yang diakibatkan krisis politik di Suriah. Hibah untuk Bosnia Herzegovina dan Serbia diberikan dalam rangka membantu penyelesaian masalah kemanusiaan yang disebabkan banjir bandang.

Hibah untuk Palestina diberikan sebagai dampak kerusakan infrastruktur dan korban jiwa akibat Israel yang melancarkan Operation Protective Edge di Gaza. Namun hibah yang direalisasikan hanya untuk Serbia dan Bosnia Herzegovina. Sementara untuk Palestina dan Suriah tidak direalisasikan karena terkendala masalah transfer dan rekening yang tidak bisa disediakan oleh beneficiary sebagai salah satu syarat pencairan belanja hibah.

Pemerintah Indonesia memberikan hibah kepada 5 negara/lembaga asing pada tahun 2015. Hibah Palestina dan Suriah direalisasikan masing-masing Rp.14,06 miliar dan Rp.7,03 miliar yang pada tahun 2014 tidak bisa dicairkan. Meskipun dicairkan, proses penyelesaiannya melalui mekanisme permintaan pengalokasian anggaran kembali dari awal setelah persyaratan pencairan sudah dapat dipastikan dapat dipenuhi. 
Pada tahun 2015 ini, hibah pembangunan masjid pada Indonesia Islamic Center (IIC) Kabul, Afghanistan, hibah untuk Indonesia Moslem Center of Queensland (IMCQ) serta hibah untuk Pemerintah Palau dalam rangka Pacific Island Forum (PIF) diberikan Pemerintah Indonesia. Masing-masing untuk masjid sebesar Rp.5 miliar, sedangkan untuk Palau sebesar Rp.12,5 miliar.

Hibah pembangunan masjid pada IIC Kabul merupakan bagian dari komitmen Pemerintah Indonesia untuk membantu proses perdamaian, rekonsiliasi dan rekonstruksi Afghanistan sebagai hasil pertemuan London Conference 2010. Sementara hibah untuk IMCQ direalisasikan atas proposal IMCQ yang disampaikan kepada Presiden dalam kunjungan di Brisbane November 2014. IMCQ sendiri merupakan lembaga sosial nirlaba yang didirikan 2012 yang mewadahi komunitas muslim Indonesia di Brisbane dan aktif dalam kegiatan kemasyarakatan, lintas agama, kepemudaan, pendidikan di kota Brisbane atau Negara Bagian Queensland.

Hibah kepada Pemerintah Palau ditujukan untuk penggunaan untuk membantu keperluan penyelenggaraan the 45th Pacific Islands Forum and Other Forum Related Meetings. Tujuan Indonesia memberikan hibah ke Pemerintah Palau dalam rangka PIF dimaksudkan sebagai gesture itikad baik Indonesia dalam meningkatkan hubungan bilateral Indonesia-Palau dan mendorong citra positif Indonesia yang berkomitmen menjadi mitra strategis Pacific Islands Forum dalam memajukan pembangunan ekonomi, keamanan, kedaulatan kawasan, dan memperkuat kerjasama kawasan dan integrasi dengan kawasan lain.

Selanjutnya pada tahun 2016 dan 2017, pemerintah Indonesia juga memberikan hibah kepada Pemerintah Laos dalam rangka keketuaan ASEAN 2016 sebesar Rp.13,11 miliar dan hibah untuk Melanesian Spearhead Group (MSG) sebesar Rp.22,65 miliar untuk kesekretariatan MSG di mana Indonesia sebagai associate member MSG.

Hibah kepada Pemerintah Laos dalam rangka keketuaan ASEAN diberikan karena keketuaan ASEAN dilakukan secara bergilir tiap tahunnya dimana hak pemerintah Laos pada tahun 2016. Laos termasuk dalam Least Developed Countries (LDCs). Hibah Indonesia merupakan wujud untuk meneguhkan peran dan kepemimpinan Indonesia di ASEAN dan upaya mempererat hubungan Indonesia dan Laos serta meningkatkan citra positif Indonesia di kalangan pemerintah dan masyarakat Laos.

Hibah kepada Melanesian Spearhead Group (MSG) bertujuan untuk memperluas peran dan engagement untuk meningkatkan posisi tawar Indonesia di kawasan Pasifik di organisasi subregional MSG yang mendukung integritas wilayah NKRI berdasarkan prinsip saling menghormati dan tidak mencampuri urusan dalam negeri masingmasing.
Realisasi belanja hibah pemerintah Indonesia pada tahun 2018 diberikan kepada pemerintah Guinea Bissau dalam rangka membantu kemanusiaan sebesar Rp.25,34 miliar, hibah kepada pemerintah Papua Nugini untuk keperluan hibah kemanusiaan korban gempa sebesar Rp.7,16 miliar, hibah kepada Pemerintah Fiji berupa alat pertanian senilai Rp.5,80 miliar dan hibah untuk pembangunan fasilitas klinik kesehatan di IIC Kabul sebesar Rp.16,17 miliar.

Pemberian hibah kepada Pemerintah Guinea Bissau merupakan salah satu instrumen diplomasi Indonesia untuk meningkatkan pengaruh dan citra positif Indonesia di Guinea Bissau dengan kerjasama yang lebih konkrit dalam rangka membantu penciptaan perdamaian melalui kesejahteraan serta pencapaian Sustainable Development Goal (SDG) 2030. Guinea Bissau adalah salah satu negara miskin di Afrika Barat yang masih tergolong Least Developed Countries (LDCs).

Hibah kepada pemerintah Papua Nugini untuk keperluan hibah kemanusiaan korban gempa merupakan bentuk solidaritas dan kemanusiaan Indonesia sebagai tetangga dan mitra komprehensif Papua Nugini dan meningkatkan citra positif Indonesia sebagai good neighbor and partner dan di level masyarakat luas sebagai upaya 'to win the heart and mind of the people'.

Hibah pemerintah Indonesia yang ditujukan untuk Pemerintah Fiji merupakan tindaklanjut kunjungan kerja Menteri Koordinator Bidang Politik, Hukum dan Keamanan ke Fiji pasca bencana angin topan Winston yang melanda Fiji tahun 2016. Pemberian hibah kepada Pemerintah Fiji ini bertujuan untuk mengimplementasikan dan memperkuat kerjasama Indonesia dan Fiji khususnya di bidang pertanian dan membantu untuk memulihkan kehidupan normal masyarakat petani Fiji salah satunya dengan peralatan pertanian.

Hibah untuk pembangunan fasilitas klinik kesehatan, di IIC Kabul yang merupakan fasilitas pelengkap IIC di samping masjid yang merupakan hibah sebelumnya tahun 2015 sebagaimana komitmen Pemerintah Indonesia kepada Pemerintah Afghanistan. Tujuan hibah untuk pembangunan klinik kesehatan di IIC adalah untuk menyediakan akses terhadap basic health service (pelayanan kesehatan dasar) untuk penduduk di sekitar IIC, yaitu kurang lebih 2.500 orang karena tidak ada basic health service dalam radius $15 \mathrm{~km}$. Kebutuhan klinik ini terutama untuk unit pelayanan ibu dan bayi, obstetrics unit, internal medicine unit dan mental health unit.

Seluruh realisasi belanja hibah periode 20142018 tersebut dilakukan melalui mekanisme tunai (cash) yang ditransfer dari rekening Kas Negara ke rekening beneficiary-nya.

Sebagai penanggung jawab kegiatan dalam kurun waktu 2014-2018, kementerian yang ditunjuk selaku penanggung jawab pelaksanaan kegiatan umumnya berdasarkan atas inisiator/pemrakarsa kegiatannya. 
Namun ada juga penanggung jawab kegiatan berdasarkan pada pendekatan tugas dan fungsi kementerian/lembaga seperti hibah untuk pembangunan asrama mahasiswa Indonesia di $\mathrm{Al}$ Azhar Cairo, Mesir yang penanggungjawabnya Kementerian Pendidikan Nasional, hibah kepada pemerintah Fiji untuk alat pertanian yang dilakukan oleh Kementerian Pertanian, hibah untuk IMAAM Center, Maryland, USA dan hibah untuk Indonesia Islamic Center (IIC) tahun 2015 berupa pembangunan masjid yang penanggungjawabnya Kementerian Agama. Namun hibah untuk IMCQ (Indonesia Moslem Center of Queensland) penanggungjawabnya Kementerian Luar Negeri. Hibah IIC Kabul berupa pembangunan klinik tahun 2018 dimana Kementerian Kesehatan ditunjuk selaku penanggung jawab kegiatannya.

\subsection{Faktor-faktor yang Mempengaruhi Pemberian Hibah Sebagai Stimulus Soft Diplomacy}

Dalam studi ini, pemberian hibah kepada pemerintah/lembaga asing dikategorikan sebagai urusan yang berkaitan dengan amal (charitable affair) sebagaimana Srivastava (2013) pertimbangkan sebagai aktivitas soft diplomacy dimana peran pemerintah Indonesia sebagai salah satu actor penting untuk berinteraksi dengan dunia internasional disamping actors yang lain berperan dalam soft diplomacy melalui berbagai aspek sosial, budaya, dan ekonomi.

Implementasi soft diplomacy ini relevan dengan keterlibatan aktor negara (pemerintah) dan nonnegara yang merupakan pelaksanaan diplomasi multi jalur (multi-track diplomacy).

Ada dua faktor yang perlu ditinjau dalam pelaksanaan pemberian hibah kepada pemerintah/lembaga asing sebagai stimulus soft diplomacy yaitu dari faktor tujuan pemberian hibah dan faktor pemerintah asing/lembaga asing sebagai penerima hibah.

\subsubsection{Tujuan Pemberian Hibah}

Selama periode tahun 2014-2018, pemberian hibah kepada pemerintah/lembaga asing dapat diklasifikasikan sebagai hibah untuk tujuan kemanusiaan dan nonkemanusiaan. Klasifikasi ini pada awal pelaksanaan hibah kepada pemerintah/ lembaga asing berkaitan dengan penyediaan dana hibah APBN di mana mekanisme penganggarannya dilakukan pada tahun anggaran berjalan dengan melakukan pergeseran anggaran belanja antar subbagian anggaran BA BUN.

Pemberian Hibah untuk tujuan kemanusiaan (humanitarian) digunakan untuk penanggulangan bencana alam dan pasca bencana, seperti hibah untuk Suriah, Bosnia Herzegovina, Serbia dan Palestina, Fiji, Guinea Bissau dan Papua Nugini untuk korban gempa.

Untuk tujuan nonkemanusiaan, hibah yang diberikan seperti untuk pembangunan asrama mahasiswa Indonesia di Al Azhar Cairo, hibah kepada
IMAAM Center, Maryland, USA, hibah untuk IMCQ, hibah untuk pembangunan Indonesia Islamic Center di Kabul, Afganistan. Penerima manfaat utamanya adalah komunitas, diaspora, mahasiswa dan orang Indonesia di luar negeri serta warga setempat. Pembangunan masjid atau Islamic community center menjadi etalase Indonesia di negara penerima dengan mempromosikan Islam rahmatan lil 'alamin.

Hibah yang diberikan lainnya berkaitan dengan aspek ekonomi (economy) negara penerima seperti hibah untuk Pemerintah Palau dalam rangka mendukung penyelenggaraan the 45th Pacific Islands Forum (PIF) and Other Forum Related Meetings yang merupakan forum negara-negara di Pasifik sebagai forum untuk peningkatan kerjasama antara Indonesia dan negara-negara anggota PIF. Hibah juga diberikan kepada Pemerintah Laos dalam rangka Keketuaan Laos pada ASEAN 2016 karena untuk membantu secara ekonomi Laos sebagai negara LDCs, dan hibah kepada Melanesian Spearhead Group (MSG) untuk mendukung operasional MSG.

\subsubsection{Pemerintah/Lembaga Asing Sebagai Penerima Hibah}

Kebijakan pemerintah dalam memberikan hibah kepada pemerintah/lembaga asing periode 20142018 memperlihatkan kecenderungan dengan perhatian yang lebih ke wilayah kawasan Asia, Pasifik dan Afrika. Hal ini dibuktikan dari arah kebijakan dan realisasi belanja hibah sebagai stimulus soft diplomasi untuk pemerintah asing/lembaga asing yang meningkat.

Realisasi total hibah untuk kawasan Asia sebesar Rp.55,37 miliar, kawasan Pasifik sebesar Rp.48,11 miliar, kawasan Afrika sebesar Rp.58,75 dan kawasan lainnya (Amerika dan Australia) sebesar Rp.43,27 miliar.

Berdasarkan jenis rekening penerima transfer yang dilakukan dari rekening Kas Negara, realisasi penerima hibah ke rekening pemerintah asing yang ditunjuk sebanyak 8 negara penerima yaitu ke rekening pemerintah Serbia, Bosnia Herzegovina, Palau, Palestina, Laos, Guinea Bissau, Papua Nugini dan Fiji.

Sedangkan realisasi penerima hibah yang ditujukan langsung kepada rekening lembaga asing sebanyak 6 lembaga yaitu hibah pembangunan asrama mahasiswa Indonesia melalui rekening Grand Syaikh Al Azhar, IMAAM Center melalui Indonesian Muslim Association in America (IMAAM), hibah pembangunan masjid dan klinik kesehatan Afganistan melalui Noor Educational and Capacity Development Organization (NECDO), hibah pembangunan masjid Queensland melalui Indonesia Moslem Center of Queensland (IMCQ), hibah ke Suriah melalui United Nations Office for the Coordination of Humanitarian Affairs (UNOCHA) dan hibah ke Sekretariat Melanesian Spearhead Group (MSG) melalui MSG Development Fund. 


\subsection{Permasalahan dalam Pelaksanaan Hibah Kepada Pemerintah/Lembaga Asing 2014- 2018}

1. Dalam pelaksanaan pemberian hibah kepada pemerintah/lembaga asing periode 2014-2018, pemerintah Indonesia telah mengalokasikan hibah untuk 16 penerima (beneficiaries) dan direalisasikan untuk 14 penerima baik pemerintah/lembaga asing. Dua penerima sisanya tidak dapat merealisasikannya pada tahun anggaran berjalan atau direalisasikan pada tahun anggaran berikutnya yakni hibah untuk Palestina dan Suriah. Kesiapan penerima hibah dan persyaratan administratif pencairan seperti permintaan salinan nomor rekening Pemerintah/ Lembaga Asing Penerima Hibah yang tidak kunjung dipenuhi menjadikan hibah tidak bisa dicairkan pada tahun anggaran berjalan dan memerlukan pengusulan kembali dari awal untuk bisa menggunakan alokasi Belanja Lainnya.

2. Pemberian hibah kepada pemerintah/lembaga asing sebagai salah satu stimulus soft diplomacy politik luar negeri Indonesia tidak hanya diberikan dari pemerintah ke pemerintah saja $(G$ to $G$ ), tetapi diberikan juga untuk lembaga asing yang terakreditasi di negaranya seperti untuk Indonesian Muslim Association in America (IMAAM), Noor Educational and Capacity Development Organization (NECDO), Indonesia Moslem Center of Queensland (IMCQ), United Nations Office for the Coordination of Humanitarian Affairs (UNOCHA) dan MSG Development Fund. Sedangkan hibah pembangunan asrama mahasiswa Indonesia melalui Grand Syaikh Al Azhar. Dari 6 lembaga asing tersebut, terdapat 3 lembaga asing yang pengurus ataupun penerima manfaatnya warga komunitas, diaspora dan orang Indonesia di luar negeri yaitu IMAAM, Maryland, IMCQ dan hibah pembangunan asrama mahasiswa Indonesia di $\mathrm{Al}$ Azhar, Cairo.

Dalam PMK No. 92/PMK.08/2014 tentang Pelaksanaan Belanja Hibah ke Pemerintah Asing/Lembaga Asing, Lembaga Asing disebutkan sebagai lembaga yang berasal dari luar negeri yang menerima hibah dari Pemerintah Indonesia.

Sebagai bagian dari strategi soft diplomacy di mana attractiveness (daya pikat) hal yang pokok, hibah dengan tujuan negara asing akan lebih maksimal tujuan dan manfaatnya jika definisi lembaga asing lebih konkrit dan spesifik sehingga akan mendorong upaya diplomasi dengan efektif.

3. Sesuai Pasal 6 Peraturan Pemerintah Nomor 45/2013 tentang Tata Cara Pelaksanaan APBN, penunjukan KPA tidak terikat periode tahun anggaran. Penunjukan KPA berakhir apabila tidak terdapat alokasi anggaran untuk program yang sama pada tahun anggaran berikutnya.

Karena alokasi anggaran belanja hibah ke pemerintah/lembaga asing pencairannya sekaligus bisa dipastikan untuk tahun anggaran berikutnya tidak terdapat alokasi untuk hal yang sama. Untuk tahun anggaran berikutnya jika terdapat alokasi belanja hibah ke pemerintah/lembaga asing, perlu diusulkan kembali KPA Belanja Hibah.

Pasal 4 ayat (2), (3), dan (4) PMK 92/MK.08/2014 mengamanatkan dalam hal terdapat alokasi belanja hibah untuk pemerintah/lembaga asing perlu keputusan Menteri Keuangan tentang KPA Belanja Hibah. Pada tahun 2014, terdapat 3 Keputusan Menteri Keuangan (KMK) tentang KPA Belanja Hibah meskipun hanya satu KMK yang menjadi dasar pencantuman di DIPA-nya. Selama itu pula, Direktur Evaluasi, Akuntansi dan Setelmen ditetapkan sebagai KPA. Keputusan Menteri Keuangan tentang penetapan KPA Belanja Hibah adalah sebagai berikut:

a. KMK No.171/KM.08/2014 tanggal 16 Mei 2014 tentang penunjukkan KPA Hibah IMAAM Center, Maryland

b. KMK No.172/KM.08/2014 tanggal 16 Mei 2014 tentang penunjukkan KPA Hibah Al Azhar, Cairo

c. KMK No.538/KM.08/2014 tanggal 17 November 2014 tentang penunjukkan KPA KPA Hibah Kemanusiaan ke Suriah, Serbia, Bosnia Herzegovina dan Palestina

Namun demikian, penunjukkan KPA Belanja Hibah menjadi sebuah permasalahan ketika terdapat alokasi Belanja Hibah ke Pemerintah Asing/Lembaga Asing dan proses pengusulannya di akhir tahun anggaran berjalan dimana terdapat kendala waktu.

Untuk mengantisipasi kendala semacam itu, sejak 2016 KPA Belanja Hibah ke Pemerintah Asing/Lembaga Asing ditetapkan dengan tanpa menyebutkan kegiatan pemberian hibah dengan spesifik per penerima hibahnya yaitu dengan KMK Nomor 640/KMK.08/2016 tentang Penunjukan Kuasa Pengguna Anggaran dalam Rangka Pemberian Hibah Pemerintah Indonesia kepada Pemerintah Asing/Lembaga Asing (BA 999.02).

Meskipun alokasi hibah ke pemerintah asing/lembaga asing merupaka pergeseran antar BA BUN namun karena program dan satker-nya sama dengan kegiatan Banking Commission maka penunjukan KPA tetap berlaku karena tetap terdapat alokasi anggaran untuk program yang sama pada tahun anggaran berikutnya.

4. Ketentuan pasal 12 ayat (1) PMK 177/MK.02/2014 tentang Tata cara Perencanaan, Penelaahan, dan Penetapan Alokasi Bagian Anggaran Bendahara Umum Negara, reviu APIP $\mathrm{K} / \mathrm{L}$ pemrakarsa kegiatan dilakukan untuk pergeseran anggaran antar sub bagian BUN (dari PPA BA 999.08 (DJA) ke BA 999.02 (DJPPR).

Namun untuk hibah pembangunan masjid di 
Queensland di mana penganggarannya tidak melalui mekanisme pergeseran anggaran, melainkan langsung ke APBNP, reviu Aparat Pengawas Internal Pemerintah (APIP) K/L dilakukan APIP Kementerian Keuangan atas anggaran yang diusulkan oleh KPA Belanja Hibah.

Meskipun kasuistis terdapat pola baru di mana alokasi anggaran belanja hibah yang tidak melalui pergeseran anggaran seperti praktik pemberian hibah yang ada dimana mekanisme yang dilakukan adalah dengan pergeseran anggaran belanja antar subbagian anggaran dalam BA BUN sesuai ketentuan PMK Nomor 93/MK.02/2013 jo 87/MK.02/2015 jo 208/PMK.02/2017 tentang Tata Cara Penggunaan dan Pergeseran Anggaran Pada BA BUN Pengelolaan Belanja Lainnya (BA 999.08)

Sementara itu, ketentuan Pasal 4 PMK 92/MK.08/2014 menyebutkan bahwa DJA memberitahukan alokasi anggaran Belanja Hibah kepada Pemimpin PPA BUN untuk diproses sesuai ketentuan perundang-undangan.

5. PMK 92/MK.08/2014 Pasal 7 mengatur hal selisih kurs pada saat pelaksanaan transfer belanja hibah ke pemerintah/lembaga asing pada tahun anggaran berjalan dengan melakukan revisi anggaran sesuai ketentuan yang berlaku.

Isu selisih kurs muncul ketika komitmen Kepala Negara dalam bentuk valas namun pada saat akan dicairkan kurs-nya berfluktuasi. Mengingat pencairan belanja hibah dalam valas, harus dilakukan revisi anggaran akibat selisih kurs dimana pagu anggaran dalam rupiah tidak mencukupinya.

Jika dalam DIPA BA 999.02 Belanja Hibah tidak terdapat pagu yang mencukupi untuk mengantisipasi selisih kurs, maka proses revisi harus melalui BA 999.08 Belanja Lainnya mengingat pagu hibah ke pemerintah/lembaga asing berasal dari pergeseran anggaran antar subbagian BUN. Untuk itu, inisiatif Kementerian/ Lembaga pemrakarsa kegiatan diperlukan untuk menyelesaikan isu tersebut dengan meminta alokasi anggaran melalui BA 999.08.

Namun jika komitmen Kepala Negara dalam rupiah untuk pemberian hibahnya, maka isu selisih kurs dalam pencairan belanja hibah tidak terdapat karena pencairan akan dilakukan mengikuti kurs transaksi pada hari tersebut sesuai dengan valas yang diajukan dalam rekening penerima hibahnya.

Salah satu isu yang terkait dengan selisih kurs terjadi untuk hibah Palau. Selisih kurs diselesaikan dengan tidak melakukan revisi DIPA tetapi dengan mengkonfirmasikan ke pemerintah Palau tentang isu selisih kurs dan pemerintah Palau dapat memahami penjelasannya bahwa terdapat bank charges dalam komponen hibah yang diterimanya.

Komitmen Kepala Negara sebesar USD1.000.110 dan dengan pagu Belanja Hibah pada DIPA sebesar Rp.12.501.375.000 dengan kurs APBN tahun 2015, 1USD ekuivalen dengan Rp.12.500. Pada saat hibah mau dicairkan, kurs tengah transaksi BI (JISDOR) saat itu berfluktuasi pada kisaran Rp.12.838-13.362 per 1 USD. Jadi terdapat kekurangan pagu kisaran Rp.338.037.180 sampai dengan Rp.862.094.820 jika hibah diberikan sesuai komitmen Kepala Negara.

Mengingat hibah ke Palau untuk mendukung konferensi the 45th Pacific Islands Forum and Other Forum Related Meetings dan waktu pencairan hibah yang mendesak dengan pelaksanaan konferensi, Kedutaan Besar RI di Manila melakukan diplomasi yang mampu meyakinkan Pemerintah Palau untuk memahami bahwa hibah yang telah dianggarkan akan dilaksanakan sesuai dengan kurs berjalan sementara kurs APBNP TA 2015 adalah Rp.12.500 per USD 1.

Isu selisih kurs selanjutnya diantisipasi dengan revisi PMK Nomor 92/MK.08/2014 dengan PMK Nomor 3/PMK.08/2016, pencairan belanja hibah bisa dilakukan dengan menggunakan valas atau rupiah.

6. Kementerian/Lembaga pemrakarsa kegiatan bertanggung jawab atas kegiatan dan pencapaian output pelaksanaan hibah ke pemerintah/ lembaga asing. Meskipun demikian, laporan sebagai wujud dari pertanggungjawaban kegiatan dan pencapaian output tidak selalu disampaikan kepada KPA Belanja Hibah. Beberapa yang melaporkan seperti Hibah ke Sekretariat MSG, dan Hibah ke Laos.

KPA Belanja Hibah bertanggung jawab secara formal dan menyusun laporan keuangan BA BUN Belanja Hibah dimana salah satunya terdapat kegiatan hibah untuk pemerintah asing/lembaga asing. Sesuai amanat Pasal 9 PMK Nomor 92/MK.08/2014 bahwa pelaporan pelaksanaan belanja hibah ke pemerintah asing/lembaga asing mengacu pada sistem akuntansi hibah dimana pelaporannya mengacu pada pelaksanaan hibah oleh KPA terkait dengan transfer belanja hibah. Namun jika laporan pelaksanaan manajerial kegiatan Kementerian/ Lembaga pemrakarsa kegiatan disampaikan kepada KPA Belanja Hibah akan melengkapi laporan keuangan yang disusun.

Pemberian hibah tetap harus mengedepankan prinsip transparansi dan akuntabilitas dengan mengingat sifat hibah sendiri yang merupakan bantuan yang spesifik ditetapkan peruntukannya, bersifat tidak wajib dan tidak mengikat, tidak secara terus menerus dan sesuai dengan kemampuan fiskal pemerintah.

\section{KESIMPULAN}

Pemberian hibah ke pemerintah/lembaga asing tahun 2014-2018 sebagai stimulus soft diplomacy 
politik luar negeri Indonesia telah mempunyai mekanisme yang tertata lebih baik dengan telah ditetapkannya PP 45 Tahun 2013 dan PMK Nomor 92/MK.08/2014. Sepanjang ada pledge Presiden atau direktifnya, ada kementerian yang bertanggung jawab atas pencapaian output dan pelaksanaan kegiatan hibah, hibah kepada pemerintah/lembaga asing dapat dilaksanakan.

KPA Belanja Hibah ada pada Kementerian Keuangan yang bertanggung jawab atas transfer tunai (cash) hibah dari Kas Negara ke rekening penerima (beneficiary). Beberapa kendalanya adalah perlunya usulan baru lagi jika belanja hibah melewati tahun anggaran berjalan untuk dapat menggunakan alokasi BUN Belanja Lainnya. Di samping itu, fleksibilitas mekanisme pemberian hibah yang terbatas pada pemberian tunai (cash). Sementara hibah dalam bentuk membiayai kegiatan tidak dikenal dalam periode 2014-2018.

Kebijakan pemerintah dalam upaya peningkatan peran dan pengaruh Indonesia sebagai negara middle power di dunia internasional tercermin salah satunya dengan memberikan hibah utamanya kepada pemerintah/lembaga asing di kawasan Asia, Pasifik dan Afrika serta kawasan lainnya. Hal ini merupakan sinyal bahwa hubungan diplomasi memerlukan stimulus untuk memperkuat kesepahaman dan kerjasama yang terjalin dengan negara lain tanpa mencampuri urusan dalam negeri masing-masing sebagaimana prinsip umum diplomasi.

Meskipun pemberian hibah sebagai stimulus soft diplomacy periode 2014-2018 disesuaikan dengan kapasitas fiskal pemerintah dan secara jumlah belum relatif besar, namun setidaknya gesture kebijakan politik luar negeri pemerintah sudah pada jalur yang tepat untuk mewujudkan visi dan misi politik luar negeri bebas-aktif Indonesia dan memperkuat jati diri sebagai negara yang cinta damai yang penuh dengan persahabatan antar negara.

Dalam periode 2014-2018, tidak semua hibah yang diberikan hanya untuk pemerintah asing. Ada alasan tertentu hibah diberikan untuk komunitas, diaspora dan orang Indonesia di luar negeri seperti misalnya hibah untuk IMAAM Center, Maryland, pembangunan masjid Indonesia di Queensland dan pembangunan asrama mahasiswa Indonesia di $\mathrm{Al}$ Azhar Cairo. Meskipun demikian, hal ini tetap menjadi salah satu etalase Indonesia di negara penerima dengan mempromosikan nilai-nilai luhur bangsa Indonesia seperti Islam yang rahmatan lil 'alamin.

\section{KETERBATASAN}

Penelitian ini terbatas dalam mendeskripsikan skema pemberian hibah kepada pemerintah/lembaga asing terbatas pada apa yang dilakukan oleh Direktorat Evaluasi, Akuntansi dan Setelmen, DJPPR selaku unit pelaksana pemberian hibah periode 2014-2018.

Keterlibatan kementerian/lembaga negara sebagai penanggung jawab kegiatan dalam pelaksanaan dan pencapaian output kegiatan belanja hibah tidak dikaji mendalam karena keterbatasan data dan informasi yang tidak tersedia pada Kementerian/Lembaga khususnya tindak lanjut dan monitoring dan evaluasi setelah transfer belanja hibah dilakukan KPA Belanja Hibah. Hal ini menjadikan penelitian pemberian hibah kepada pemerintah/lembaga asing sebagai stimulus soft diplomacy tidak komprehensif mengingat dampaknya yang tidak langsung dan jangka panjang.

Untuk penelitan di masa mendatang perlu dilakukan pengkajian dengan meneliti faktor-faktor di luar keterbatasan saat ini dengan memperhatikan peraturan baru terkait pemberian hibah yaitu PP 48 Tahun 2018 tentang Tata cara Pemberian Hibah kepada Pemerintah Asing/Lembaga Asing yang telah dirubah terakhir dengan PP 57 Tahun 2019.

\section{DAFTAR PUSTAKA \\ Peraturan}

UU Nomor 17 Tahun 2003 tentang Keuangan Negara

UU Nomor 1 Tahun 2004 tentang Perbendaharaan Negara

UU Nomor 27 Tahun 2014 tentang APBN Tahun Anggaran 2015

Peraturan Pemerintah Nomor 45/2013 Tentang Pelaksanaan APBN sebagaimana telah diubah dengan Peraturan Pemerintah Nomor 50/2018

Peraturan Pemerintah Nomor 48 Tahun 2018 tentang Tatacara Pemberian Hibah kepada Pemerintah Asing/Lembaga Asing

Peraturan Menteri Keuangan Nomor 92/MK.08/2014 tentang Pelaksanaan Belanja Hibah ke Pemerintah Asing/Lembaga Asing sebagaimana telah diubah dengan Peraturan Menteri Keuangan Nomor 3/PMK.08/2016

Peraturan Menteri Keuangan Nomor 204/MK.02/2014 jo Nomor 100/MK.02/2015 tentang Tata cara Pergeseran Anggaran Belanja Antar Subbagian Anggaran dalam Bagian Anggaran 999 (BA BUN)

Peraturan Menteri Keuangan Nomor 177/MK.02/2014 tentang Tata cara Perencanaan, Penelaahan, dan Penetapan Alokasi Bagian Anggaran Bendahara Umum Negara

Peraturan Menteri Keuangan Nomor 190/PMK.05/2012 tentang Tata Cara Pembayaran Dalam Rangka Pelaksanaan Anggaran Pendapatan Dan Belanja Negara

Peraturan Menteri Keuangan No. 271/PMK.05/ 2014 tentang Sistem Akuntansi dan Pelaporan Hibah

\section{Non Peraturan}

Arista, Fiky.2016. Politik Luar Negeri Bebas Aktif Indonesia. Universitas Pendidikan Indonesia

Buletin Teknis No. 13 tentang Akuntansi Hibah.

C.P.F Luhulima. Peranan Diplomasi Multi-track dalam Penyelesaian Sengketa Laut China Selatan; Upaya 
dan Tantangan. Jurnal Ilmiah Hubungan Internasional, 5(2). Hal 75

Enggartias Wahana Putera, Esensi Hubungan Internasional dan Kebijakan Politik Luar Negeri Indonesia

Andri Hadi "Diplomasi Publik dalam Kebijakan Luar Negeri Republik Indonesia", disampaikan pada Kuliah Umum Jurusan Hubungan Internasional Universitas Islam Negara Syarif Hidayatullah (Jakarta, September 2008)

Hocking, B., "Rethinking the 'New' Public Diplomacy," dalam J. Melissen (ed.), The New Public Diplomacy: Soft Power in International Relations. Basingstoke: Palgrave Macmillan, 2005. Hlm. 41

Kurniadi, Taraf. 2015. Kuasa Pengguna Anggaran (KPA) dalam Pelaksanaan Belanja Hibah Pemerintah Ke Pemerintah Asing/Lembaga Asing. Paper

Lexy. J. Moleong. 2000. Metodologi Penelitian Kualitatif. Bandung: PT Remaja Rosdakarya

Mangowal, Stella Edwina. 2010. Soft Power Jepang: Studi Kasus JENESYS (Japan-East Asia Network of Exchange for Students and Youths). Jakarta: Universitas Indonesia

Noor Cholis Madjid. (2013) Pengujian dan Pembayaran Tagihan, Pusdiklat Anggaran dan Perbendaharaan,

Nye, Joseph S, 2008. Public Diplomacy and Soft Power. The ANNALS of the American Academy of Political and Social Science, Vol 616, Issue 1, pp. 94 -109, First Published March 1, 2008

Perwita, Anak Agung Banyu. Diplomasi Ekonomi Indonesia.

https://nasional.kompas.com/read/2008/04/2 8/01253873/diplomasi.ekonomi.indonesia. Diakses pada tanggal 25 Juni 2019 pukul 14.47 WIB

Srivastava, Vivek Kumar.2013. Soft Power and Soft Diplomacy: Nature, Comparison, and Impact. Paper.

Sijabat, Heryanto (2014) Akibat Hukum Tanggung Jawab Administratif Pejabat Pembuat Surat Perintah Membayar (PPSPM) dalam Pencairan Belanja Negara. Paper, didownload dari www.bppk.kemenkeu.go.id

Soesilowati, Sartika. Diplomasi Soft Power Indonesia melalui Atase Pendidikan dan Kebudayaan. https://e-

journal.unair.ac.id/JGS/article/view/6915.

Diakses pada tanggal 1 Juli 2019 pukul 17.48 WIB

Sriyani. Analisis Akuntansi Dan Pelaporan Bantuan Sosial dan Hibah.

http://jurnal.pknstan.ac.id/index.php/JIA/artic le/download/35/25. Diakses pada tanggal 6 Juli 2019 pukul 11.30 WIB

Sudarwan Danim, 2002. Menjadi Peneliti Kualitatif Rancangan Metodologi, Presentasi, dan Publikasi Hasil Penelitian untuk Mahasiswa dan Penelitian Pemula Bidang Ilmu Sosial, Pendidikan, dan
Humaniora. Bandung: Remaja Rosdakarya, Cet. I, hlm. 51.2

Suryokusumo, Sumaryo. 2004. Praktik Diplomasi. Jakarta: STIH IBLAM

Szondi ,György. Central and Eastern European Public Diplomacy: A Transitional Perspective onNational Reputation Management dalam Nancy Snow dan Philip Taylor (ed.).

Yani, Yanyan Mochamad \& Elnovani Lusiana. Soft Power dan Soft Diplomacy dalam Jurnal TAPIs Vol. 14 No.02 Juli-Desember 2018 